\title{
INTEGRATED LINKAGES TO THE SUSTAINABILITY OF DINOYO CERAMIC VILLAGE, MALANG
}

\author{
${ }^{* * 1}$ Efani, Anthon, ${ }^{2}$ Manzilati, Asfi \& ${ }^{3}$ Sambah, Abu Bakar \\ ${ }^{* 1}$ Faculty of Fisheries and Marine Sciences Universitas Brawijaya, Malang, Indonesia \\ ${ }^{2}$ Faculty of Economics and Business Universitas Brawijaya, Malang, Indonesia \\ ${ }^{3}$ Faculty of Fisheries and Marine Sciences Universitas Brawijaya, Malang, Indonesia
}

\begin{tabular}{l}
\hline \hline ARTICLE DETAILS \\
\hline Article History \\
Published Online: publisher use \\
only
\end{tabular}

\section{Keywords}

Dinoyo ceramic village, online social media, online media partnership, marketing strategy

"Corresponding Author

Email: anthonefani@gmail.com

\begin{abstract}
Dinoyo is a ceramic handicraft center in Malang City. The cultural potential of the Dinoyo people, especially ceramic craftsmen, which has survived to this day is one of the fulcrums for cultural preservation efforts. The purpose of this research is to create a marketing strategy, to improve the sustainability of the Dinoyo Ceramic Village both in terms of production and function of the village as a center for literacy and cultural preservation in Malang City and one of them is through the optimization of promotional media to increase sales and support promotional events in Dinoyo Ceramic Village. The method used in this research is descriptive qualitative structured interviews. The results showed that the dinoyo ceramic village had not made good use of the marketing strategy so that it needed optimization of online media partnerships and the use of online social media. Thus this research contributes to increasing the competitiveness of dinoyo ceramics in order to improve community welfare.
\end{abstract}

\section{Introduction}

MSME (Micro Small Medium Enterprise) is a type of business that has an important role in increasing the GDP (Gross Domestic Product) of a country, especially in Indonesia by facing the Industrial Era 4.0. MSME 4.0 is beginning to recognize advances in computerized power, artificial intelligence, robotics, and materials science that can accelerate the shift towards more environmentally friendly products of all kinds. Prepare yourself for the development of new energy technologies that can create cheap, abundant and sustainable resources. The scale and breadth of technological innovation has revolutionized the way MSME 4.0 do business. MSME 4.0 can begin to explore how the Industrial Revolution 4.0 can affect individuals and society. However, MSME 4.0 can take the first steps first to create big changes in business (Amri, 2020; Alfrian \& Pitaloka, 2020)

In the effort to empower the MSME sector which is one of the strong foundations of the economy, it turns out that it still has several problems in its development, such as: access to financial resources, both to financial

Faculty of Economics and Business,

Universitas Brawijaya institutions, both banks and non-banks, the human capital capacity of MSME players is still low, product innovation capability, limited marketing and business network capacity, low production technology capabilities, and weak managerial and human resource capabilities have resulted in small entrepreneurs being unable to run their businesses properly (Hanifah et al., 2020; Suci et al., 2017)

Dinoyo Village is a center for ceramic handicrafts in Malang City. The cultural potential of the community, especially ceramic craftsmen, which has survived to this day, is one of the bases in efforts to preserve the culture itself (Yana, 2014; Wisesa, 2020). The development of ceramic handicrafts in Dinoyo from time to time has experienced various conditions, both positive and negative. To meet the demand for ceramic handicrafts, the craftsmen have even studied the combustion system since 1990 until now in various places in Indonesia. Until now, the craftsmanship of the craftsmen could not be underestimated. They are able to maintain the existence of Dinoyo ceramics even though the demand is decreasing. 
Ceramics, which used to be a primary necessity such as eating and drinking utensils and other household appliances, are now increasingly used as decorations (Purwanto, 2015). As is done by ceramic craftsmen in Dinoyo, to keep up with the times and people's tastes, the craftsmen have started to develop designs, colors and patterns to make them more attractive to the public. In addition to making ceramics invincible, craftsmen also produce ceramics based on people's preferences.

Previous research on ceramic business is very limited, for example research (Purwanto, 2015; Jamaludin, 2017; Ponimin, 2018) which still focuses on the artistic aspect of ceramics and has not discussed related to increasing business sustainability. Empirical facts also explain that the decline in demand and competition with cheap ceramics is a serious problem for the sustainability of Dinoyo Ceramics. Therefore this study aims to improve the sustainability of the Dinoyo Ceramic Village, both in terms of production and village functions. as a center for literacy and cultural preservation in Malang City and create marketing strategies, one of which is through the optimization of promotional media to increase sales and support promotional events in Dinoyo Ceramic Village to increase productivity and sales through several mentoring activities

\section{Method}

\subsection{Research Location}

The research was conducted in the Dinoyo Ceramic Village (Figure 1). The history of the ceramic industry in Malang City began in 1953 when the Organization for Organizing Industrial Companies at the Ministry of Industry (LEPPIN) was formed. Then came pilot ceramic companies in the areas of KY 1 Jakarta, KY 2 Loka Surabaya, KY 3 Purwokerto, KY 4 Mayong Jepara, KY 6 Tulungagung. In 1957, LEPPIN established Dinoyo Ceramic Factory in Malang City with the name KY 5. Dinoyo Ceramic Factory is a ceramic processing pilot project by taking advantage of new, more advanced technologies at that time, namely the slip casting \& jiggering system. The resulting products include: plates, cups, moci, stale, so it is known as the plate factory. In 1968 the units separated from the main company/KY to develop their own business. At that time, decorative ceramics in the form of dolls (noveltic ceramics) were also developed.

The unique characteristics of Dinoyo ceramic products lies in the natural color and design that characterizes a tropical country. The shapes and functions also vary, such as aromatherapy containers, flower vases, decorative jars, souvenirs and others.

Since 1998, the Dinoyo ceramics association has realized about 33 craftsmen who are active in various activities related to product innovation and marketing of their products. Dinoyo's ceramic products are marketed in big cities such as Surabaya, Jakarta, Denpasar and Medan. Besides that, the craftsmen also often participate in the MSME product show events held by the government at regional, provincial, national and international scales (Anista, 2018; Akbar, 2013).

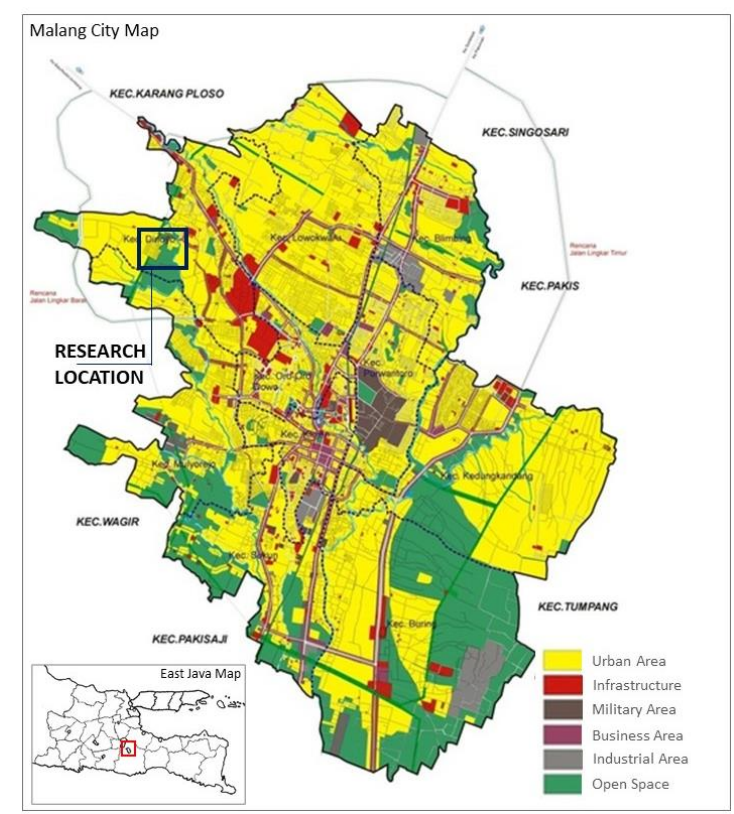

Figure 1. Research location

\subsection{Dataset}

This research was a qualitative descriptive study. Qualitative research relies heavily on field data obtained through informants, respondents, documentation or observation in social settings related to the subject under study (Bachri, 2010). The source used is primary data obtained through structured interviews.

The current study applied survey approach, interviews, and documentation. Observation was carried out directly at the research location related to the existence of the research object and everything related to research variables. interviews were conducted to collect primary data directly, where a number of respondents had been used in data collection. Respondents are members of the Dinoyo Ceramic Association which consists of the chairman and active members with a total of 25 respondents. 


\section{Integrated Linkages to The Sustainability of Dinoyo Ceramic Village, Malang}

Research variables or information collected in order to answer the research objectives are the existing business conditions of Dinoyo ceramics, active craftsman activities, problems and challenges faced by craftsmen, product innovation efforts, and product marketing systems.

\subsection{Method}

Respondents was selected by the snowball method, which was taking a number of cases through the relationship between one person and another or one case with another, then looking for further relationships through the same process, and so on (Nurdiani, 2014). The data collection method uses structured interviews so that researchers obtain complete and accurate information. So that the purpose of this research can be achieved properly.

Moreover, based on the research variables, the analysis was carried out to determine the marketing and promotion strategies used. Structured analysis was carried out by tabulating the results of the interviews regarding the variables of strengths, weaknesses, threats and opportunities. This can be done through identification and analysis including determining relevant market, analyzing primary demand for relevant markets, analyzing selective demand in relevant markets, establish market segments, assessing competition, and identifying potential target markets

\section{Discussion}

\subsection{Characteristics of Dinoyo Ceramic Village}

The cultural potential of the community, especially ceramic craftsmen, which has survived to this day is one of the foundations for cultural preservation itself (Qorib \& Syahida, 2018). The development of ceramic handicrafts in Dinoyo from time to time has experienced various conditions, both positive and negative. To keep pace with the increasing demand for ceramic crafts, craftsmen even learned about the combustion system using a pressurized spiral blander and LPG fuel in 1990 by conducting a comparative study at the Center for Ceramics and Ceramics in Kiara Condong, Bandung. Until now, the craftsmanship of the craftsmen could not be underestimated. They were able to maintain the existence of Dinoyo ceramics even though the demand had decreased.

Ceramics, which used to be a primary necessity such as eating and drinking utensils and other household appliances, are now increasingly being used as decorations. As is done by ceramic craftsmen in Dinoyo, to keep up with the times and people's tastes, the craftsmen have started to develop designs, colors and patterns to make them more attractive to the public. In addition to making ceramics invincible, craftsmen also produce ceramics based on people's preferences. The types of ceramics that are most sought after by buyers are; (a) ceramic vase (25\%); (b) ceramic souvenirs (35\%); (c) ceramic jars (10\%); (d) ceramic light sets $(10 \%)$; (d) ceramic aroma therapy $(20 \%)$.

The products being sold are creative ideas developed by craftsmen and ceramics traders. Continuous innovation and continuously adjusted to market developments and demands (Indirhastuti, 2019). Dinoyo Ceramic Village as a center for ceramic handicrafts in Malang City has a cultural potential that can be developed. In addition to increasing productivity and sales through the optimization of promotional media, this activity also seeks to open access to Dinoyo Ceramics for various innovations. One of them is the initiation of cooperation to fulfill unique souvenirs. This effort is expected to be a pioneer in the use of ceramics.

Optimization of media marketing is carried out by tidying up the appearance of social media to increase online user visits and convey the value of Dinoyo Ceramic Village. Dinoyo ceramic village has current and unsolved problems. For example, ineffective village promotion media, social media is limited to google maps whose features do not accommodate the needs of residents

\subsection{Optimization of online media partnership}

Judged to be more independent and provide many benefits, doing business is a type of work that is in great demand by people. However, to create a successful business, many important elements are needed (Robie, 2000). One of them is doing online media partnerships through brand management or what is commonly referred to as brand management (Lubis, 2017). Brand management is a vital element in determining business development. How a brand can be recognized by many people and find its own market share is a process of brand management. Brand management is an important part of the marketing strategy. How to make a brand or brand to be remembered, recognized, and sought after by consumers by 
giving a deep impression that tends to be different from similar products (competitors) (Sukmadewi, 2018).

Brand management is an ongoing process to create brands with positive values that are in line with company goals (Angraeni et al., 2019). Thus, the equity and commercial value of the brand increases, not only in a certain time but in the long term. In general, brand management consists of intangible components and tangible components. Intangible components are intangible components that measure the success of a brand. Some of these components are Brand Awareness, Brand Equity, Brand Loyalty, Brand Recognition, and Brand reputation. All of these components are related to consumers' views and how well they know the products being marketed (Sukiarti et al., 2016).

E-Commerce is a business transaction of goods and services that is carried out electronically using the internet network. Media brand management can be used to increase sales turnover as well as product marketing media to reach a wider market (Cahyo \& Candiwan, 2020; Ahmad et al., 2017).

During this pandemic, in the last 4 months, the sales of ceramic SMEs have decreased by up to $60 \%$. Every month Dinoyo ceramics MSME is able to produce 10,000 products / month, but currently it is only able to produce around 3500 products / month. This condition is certainly threatened by the survival of Dinoyo Keramik MSME. The hope is that this blind ecommerce can increase sales consistently and can develop marketing. The existence of $e$ commerce can be used as a means to increase product sales amid this pandemic (Hardilawati, 2020; Fadly \& Sutama, 2020).

\subsection{Utilization of online social media}

Online media is no longer something foreign to Indonesians. Currently, online media seems to be the main need of society, especially millennials in Indonesia. All forms of business have also recognized the role of social media in increasing their sales through promotions carried out via social media such as radio advertising websites, TV fish, Facebook, YouTube, TikTok, WhatsApp and so on (Ames \& Naaman, 2007).

The development of online media has changed the communication patterns of today's society. People now like to write comments on any issue, both personal and social issues on social media. The articles written on the network will be able to spread immediately to various parts of the world (Permatasari \& Kuswadi, 2017) so that the dissemination of information is no longer just by word of mouth, but also through social media.

Dinoyo ceramics have been widely recognized by the people of Malang Raya and outside Malang, especially for ceramic craft lovers. Since 1957 until now, Dinoyo Ceramic crafts have continued to exist and continue to develop in order to survive. Until now, there are seven craftsmen who still produce ceramic crafts in Dinoyo Village. This is because they are able to survive and keep up with changing trends and tastes of society. In the midst of a pandemic like now, it is undeniable that the demand for Dinoyo's ceramic products has fallen drastically. Limited activities of residents during the pandemic have made the production workshops less busy as before. But over time, Dinoyo ceramic craftsmen were able to survive with innovation and make products to order (Aliyani Firdaus et al., 2020).

The COVID-19 pandemic still provides opportunity for Dinoyo ceramic craftsmen who have received many order cancellations from customers. The prohibition of the community from holding party events caused many orders for party souvenirs to be canceled. However, the craftsmen continue to innovate so that they can still produce ceramics such as soap bottles and hand sanitizers. The "at home only" campaign and the phenomenon of working from home for workers have apparently gone crazy in the community, namely gardening, so that currently product orders have shifted to flower pots and other items related to hobbies such as bird cage equipment and so on.

The spirit of the craftsmen who never stops is a tremendous potential for Dinoyo Ceramic Village. This potential development is continuously being carried out so that Dinoyo Ceramic Village can become an icon of Malang City.

One way that can be done is to make promotional media effective through an online system (Ahyuna et al., 2013). This step is taken by activating village social media which can provide information to the community about Dinoyo Ceramic Village, including:

\section{a. Website}

A website or website is a collection of information in the form of web pages that are 


\section{Integrated Linkages to The Sustainability of Dinoyo Ceramic Village, Malang}

joined to one another in a domain or URL. For example, on a website with the cikenblekpaper.com domain, there are various other pages, ranging from blogs, menus, contact pages, and so on that can be accessed directly from the homepage (Mashadi et al., 2019). The website is also a marketing medium that can be used as a media for promotion and education of dinoyo ceramic products.

Through the website, it is hoped that village activities can be well documented so that they can provide information to the community. In addition, this website can also be an effective means of promoting products and community activities such as creative ceramic design competitions. In terms of population, the dinoyo ceramic village not only has the appeal of ceramic crafts, but also cultural arts and education activities that will continue to be developed so that the village is not only a place but also a literacy center

\section{b. Facebook}

Facebook is one of the many Social Networks or Social Networking Sites on the web. Facebook has become the largest social networking site today, there are so many benefits of Facebook that can be used, one of which can be used as a medium for online promotion (Wilson et al., 2012). This will make it easier for Dinoyo's ceramic village to market its products.

\section{c. Youtube}

Youtube is a media sharing site (media sharing), which is a type of social media that facilitates users to share media, ranging from video, audio, and images (Tufekci, 2018). Through YouTube, it is hoped that the Dinoyo ceramic village will be increasingly recognized by the wider community.

\section{d. Tiktok}

Tiktok is a social network and music video platform from China that allows users to create their own short music videos. The advantage of the TikTok application compared to other applications is the absence of advertisements (Domingues et al., 2020). This of course makes it easy for its users. The advantages of this tiktok can be used for branding ceramic products in Dinoyo village.

So far, the existence of social media with the name Dinoyo Ceramic Village is owned by individuals. There is no official account from the village that can interpret the culture of the community and the ceramic craft itself. With the official website of Dinoyo Ceramic Village, it is hoped that the information will be centered on the website and in the future there will be seen the creation of official social media for other villages.

\subsection{Product Quality Sustainability Strategy}

As a means to improve the sustainability of the quality of the Dinoyo Ceramic Village products, both in terms of production and the function of the village as a center for literacy and cultural preservation in Malang, a strategy is needed. The strategy will be useless if there is no sustainable program to ensure product quality through socialization, mentoring and evaluation (Dellia Mila Vernia et al., 2020). Then the strategies used to improve product quality are as follows:

1. Socialization, mentoring and guidance to the Dinoyo Ceramics MSME group about marketing innovations, and marketing strategies so as to increase the competitiveness of Dinoyo Ceramics MSME. Besides that, it can also increase the range of a wider and more commercial product (Aksa, 2018). The outreach process and general training are still being carried out. Business management assistance including production logbooks, packaging repair, and marketing.

2. Monitoring and evaluation of the continuous implementation of progress and continuity of activities involving relevant stakeholders. The monitoring and evaluation process is ready to perfect the production process and management of MSME management which is carried out once a month

Some recommendations that can be used as a reference from the results of this study are the optimization of the use of online media in product promotion and marketing. This can be done through;

(a) Advance market segmentation. Market segmentation can be made based on demographic data, namely market segments based on age, economy, city, and level of education. Online media selection must be adjusted to this demographic segment so that it is more targeted;

(b) In relation to increasing marketing and innovation capabilities, it is necessary to conduct trainings on the use of current online promotional media for craftsmen. This activity can be carried out in cooperation with government agencies and academics;

(c) As the government's effort to promote ceramic products through online social media, brand ambassadors or influencers 
are needed as strong personal branding for the target market;

(d) Regular monitoring and evaluation activities need to be carried out in order to see the achievements and obstacles faced so that their resolutions can be immediately resolved.

\section{Conclusion}

The study aims to increase the sustainability of ceramic business activities in the ceramic village of Dinoyo, Malang. Several research variables were collected through the approach of observation, documentation, and interviews with a number of craftsmen to identify issues related to the object of research. These issues include the identification of business strengths, weaknesses, threats and opportunities. The results of the study explain that innovation and marketing strategies are two important things in maintaining the sustainability of ceramic business activities in the Dinoyo ceramic village. Product innovation can be done through the craftsmanship's creative power which can be obtained through formal training activities or not. Furthermore, marketing and product promotion methods are carried out through the use of the rapidly growing digital era, namely social media platforms, where the selection can be made based on target market segmentation.

The integration link between stakeholders and Dinoyo Ceramic Village can help improve the existence of Dinoyo Ceramic Village as a literacy center and cultural preservation in Malang City. The use of online media partnerships and online social media as a media marketing strategy can increase sales of dinoyo ceramic products and increase branding of ceramic products. The research may contribute to increase the empowerment of MSME especially Dinoyo Ceramic Village in terms of the improvement of marketing strategy and product quality sustainability.

\section{References}

Ahmad, D., Ariessanti, H. D., \& Awaliyah, K. (2017). Implementation of E-Commerce Website to Increase Online Sales of Case Study of Baby Wise BSD Tangerang. Aptisi Transactions on Management (ATM), 1(1), 11-16.

https://doi.org/10.33050/atm.v1i1.680

Ahyuna, Hamzah, M. D., \& HM, M. N. (2013). Pemanfaatan Internet Sebagai Media Promosi Pemasaran. Jurnal Komunikasi KAREBA, 2(1), 30-40. http://journal.unhas.ac.id/index.php/kareba/ article/view/346

Faculty of Economics and Business,

Universitas Brawijaya
Akbar, N. F. (2013). Pengembangan Kampung Wisata (Studi Tentang Pengembangan Sentra Keramik Dinoyo Menjadi Kampung Wisata Di Kelurahan Dinoyo, Kecamatan Lowokwaru, Kota Malang). Jurnal Administrasi Publik, 1(8).

Aksa, Y. A. D. (2018). Media konvensional \& sosialisasi pemerintah desa. Jurnal Makna, 3(2), 1-18.

Alfrian, G. R., \& Pitaloka, E. (2020). Strategi Usaha Mikro, KEcil, dan Menengah (UKM) Bertahan pada Kondisi Pandemik Covid 19 di Indonesia. Seminar Nasional Terapan Riset Inovatif (SENTRINOV) Ke-6, 6(2), 139-146.

Aliyani Firdaus, S., Fadilah Ilham, I., Putri Aqidah, L., Aliyani Firdaus, S., Agung Dwi Astuti, S., \& Buchori, I. (2020). Strategi UMKM untuk Meningkatkan Perekonomian selama Pandemi Covid-19 pada saat New Normal. OECONOMICUS Journal of Economics, 5(1), 46-62. https://doi.org/10.15642/oje.2020.5.1.46-62

Ames, M., \& Naaman, M. (2007). Why we tag: Motivations for annotation in mobile and online media. Conference on Human Factors in Computing Systems . Proceedings, 971-980. https://doi.org/10.1145/1240624.1240772

Amri, A. (2020). Dampak Covid-19 Terhadap UMKM di Indonesia. Jurnal Brand, 2(1), 147-153.

Angraeni, Baharuddin, \& Mattalatta. (2019). Jurnal Mirai Management Jurnal Mirai Management. Jurnal Mirai Managemnt, 4(2), 122-136. https://journal.stieamkop.ac.id/index.php/m irai

Anista, J. S. A. (2018). Peran Paguyuban Industri Keramik Dinoyo Kota Malang Dalam Peningkatan Inovasi Produk (Tinjauan Ekonomi Islam). Tesis. Magister Ekonomi Syariah. Universitas Islam Negeri Maulana Malik Ibrahim. Malang.

Bachri, B. S. (2010). Meyakinkan Validitas Data Melalui Triangulasi Pada Penelitian Kualitatif. Teknologi Pendidikan, 10, 46-62.

Cahyo, M. R. D., \& Candiwan, C. (2020). Analysis and Design of Sales Information System on Web-Based E-Commerce in Yoga Farm Catfish Breeding Business Using UML. Jurnal Media Informatika Budidarma, $\quad 4(3), \quad 683$. https://doi.org/10.30865/mib.v4i3.2106 


\section{Integrated Linkages to The Sustainability of Dinoyo Ceramic Village, Malang}

Dellia Mila Vernia, Widiyarto, S., Dwi Narsih, Mu'thia Mubashira, \& Leni Tiwinyanti. (2020). Sosialisasi Dan Pembekalan Strategi Pemasaran Produk Olahan Pisang Pada Siswa Pondok. Jurnal Pengabdian UntukMu NegeRI, 4(1), 125-128. https://doi.org/10.37859/jpumri.v4i1.1919

Domingues, P., Nogueira, R., Francisco, J. C., \& Frade, M. (2020). Post-mortem digital forensic artifacts of TikTok Android App. ACM International Conference Proceeding Series, August. https://doi.org/10.1145/3407023.3409203

Fadly, H. D., \& Sutama. (2020). Membangun pemasaran online dan digital branding ditengah pandemi covid-19. Jurnal Ecoment Global: Kajian Bisnis Dan Management, 5, 213-222.

Hanifah, S., Sarpingah, S., \& Putra, Y. (2020). The Effect of Level of Education, Accounting Knowledge, and Utilization Of Information Technology Toward Quality The Quality of MSME's Financial Reports. April. $\quad$ https://doi.org/10.4108/eai.3-22020.163573

Hardilawati, W. laura. (2020). Strategi Bertahan UMKM di Tengah Pandemi Covid-19. Jurnal Akuntansi Dan Ekonomika, 10(1), 89-98.

https://doi.org/10.37859/jae.v10i1.1934

Indirhastuti, M. R. T. sasongko; P. (2019). Meningkatkan Keunggulan Bersaing Produk Melalui Inovasi Dan Orientasi Pasar Pada Usaha Sektor Industri Kreatif Di Kota Malang. JurnalEKBIS, 20(1), 1194-1205.

Jamaludin, Y. N. (2017). Visualisasi Seni Keramik Karya F. Widayanto. Pantun, 2(2), 150-158.

https://jurnal.isbi.ac.id/index.php/pantun/art icle/view/764

Lubis, D. I. D. R. H. (2017). Pengaruh Citra Merek dan Harga terhadap Keputusan Pembelian pada Sekolah Tinggi IImu Manajemen Sukma Medan. Dictionary of Statistics \& Methodology, 5(1), 15-24. https://doi.org/10.4135/9781412983907.n1 598

Mashadi, M., Nurachmad, E., \& Mulyana, M. (2019). Analisis Deskriptif Penilaian Website Perguruan Tinggi. JAS-PT (Jurnal Analisis Sistem Pendidikan Tinggi Indonesia), 3(2), 97. https://doi.org/10.36339/jaspt.v3i2.278

Nurdiani, N. (2014). Teknik Sampling Snowball dalam Penelitian Lapangan. ComTech:
Computer, Mathematics and Engineering Applications, $\quad 5(2), \quad 1110$. https://doi.org/10.21512/comtech.v5i2.242 7

Permatasari, A., \& Kuswadi, E. (2017). The Impact of Social Media on Consumers Purchase Intention: A Study of Ecommerce Sites in Jakarta, Indonesia The Impact of Social Media on Consumers ' Purchase Intention: A Study of Ecommerce Sites in Jakarta , Indonesia. Review of Integrative Business and Economics Research, 6(1), 321-335.

Ponimin, P. (2018). Diversifikasi Desain Produk Sentra Keramik Dinoyo Bersumber Ide Budaya Lokal Malang. Bahasa Dan Seni : Jurnal Bahasa, Sastra, Seni, Dan Pengajarannya, 46(1), 111-123. https://doi.org/10.17977/um015v46i12018p 111

Purwanto, A. (2015). Modal Budaya dan Modal Sosial dalam Industri Seni Kerajinan Keramik. MASYARAKAT: Jurnal Sosiologi, 18(2).

https://doi.org/10.7454/mjs.v18i2.3727

Qorib, F., \& Syahida, A. R. (2018). Pola Komunikasi Pariwisata Pengrajin Keramik Di Kelurahan Dinoyo Kota Malang. Reformasi, 8(2), 151. https://doi.org/10.33366/rfr.v8i2.1102

Robie, D. (2000). Spicol Daily: A Pacific Media Partnership Case Study. 1(8), 34-41.

Suci, Y. R., Tinggi, S., \& Ekonomi, I. (2017). Perkembangan UMKM (Usaha Mikro Kecil Menengah) di Indonesia. Jurnal IImiah Fakultasi Ekonomi, 6(1), 51-58.

Sukiarti, L., H, L. B., \& Haryono, A. T. (2016). Pengaruh Citra Merek, Sikap Merek, Kesadaran Merek dan Kualitas Merek terhadap Ekuitas Merek, Hand \& Body Lotion Vaseline ( Studi Kasus Di Kecamatan Pringapus, Kabupaten Semarang ). Journal of Management, 2(2), $1-26$.

https://jurnal.unpand.ac.id/index.php/MS/ar ticle/view/519/505

Sukmadewi, Y. D. (2018). Kajian Legalitas Dan Manajemen Merek Pada UMKM Munaku Sulam Pita Semarang. Law Reform, 14(2), 275. https://doi.org/10.14710/Ir.v14i2.20874

Tufekci, Z. (2018). Advertising helps fund Times journalism. 1-5. https://www.nytimes.com/2018/03/10/opini on/sunday/youtube-politics-radical.html 
Wilson, R. E., Gosling, S. D., \& Graham, L. T. (2012). A Review of Facebook Research in the Social Sciences. Perspectives on Psychological Science, 7(3), 203-220. https://doi.org/10.1177/1745691612442904

Wisesa, T. P. (2020). Pemanfaatan Teknologi Cetak 3 Dimensi Sebagai Upaya Pelestarian Gerabah Bentanga. IdealogyJournal, 5(1), 179-195.

Yana, D. (2014). Potensi Kerajinan Keramik Dalam Seni Tradisi Pertunjukan Indonesia. Panggung, 24(4). https://doi.org/10.26742/panggung.v24i4.1 31 